\title{
Retraction Note: Who performs the preoperative examination?
}

Hironobu Ueshima* and Hiroshi Otake

Retraction Note: JA Clin Rep (2018) 4:21

https://doi.org/10.1186/s40981-018-0161-6

The Editor-in-Chief has retracted this article [1]. Following an investigation by the editorial board, it was found that the information presented in the Letter to the Editor is not reliable because the clinical pathway of the patient was not accurately reported.

All authors agree to this retraction.

Published online: 03 June 2020

\section{Reference}

1. Ueshima H, Otake H. Who performs the preoperative examination? JA Clin

Rep. 2018;4:21 https://doi.org/10.1186/s40981-018-0161-6.

The original article can be found online at https://doi.org/10.1186/s40981018-0161-6.

* Correspondence: ueshimhi@yahoo.co.jp

Department of Anesthesiology, Showa University Hospital, Tokyo, Japan

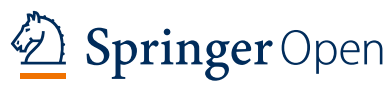

(อ) The Author(s). 2020 Open Access This article is licensed under a Creative Commons Attribution 4.0 International License, which permits use, sharing, adaptation, distribution and reproduction in any medium or format, as long as you give appropriate credit to the original author(s) and the source, provide a link to the Creative Commons licence, and indicate if changes were made. The images or other third party material in this article are included in the article's Creative Commons licence, unless indicated otherwise in a credit line to the material. If material is not included in the article's Creative Commons licence and your intended use is not permitted by statutory regulation or exceeds the permitted use, you will need to obtain permission directly from the copyright holder. To view a copy of this licence, visit http://creativecommons.org/licenses/by/4.0/. 